\title{
GRAMMATICAL ERRORS IN STUDENTS'APPLICATION LETTERS: A CASE STUDY AT IPB INTERNASIONAL
}

\author{
Muhamad Nova1, Francisca Titing Koerniawaty ${ }^{2}$ \\ 1,2 Institut Pariwisata dan Bisnis Internasional \\ 1 mnov493@ipb-intl.ac.id, ${ }^{2}$ koe.titing@gmail.com
}

\begin{abstract}
In the professional sector, both spoken and written English communications become essential skills to be mastered by vocational students. However, as a non-native speaker, errors in writing are still faced as an obstacle for the students in applying their English capability. This research aimed at identifying the grammatical errors occurring in vocational students' writing to overcome the error fossilization. The study was conducted in one vocational school in Denpasar, with a total of 45 students purposively selected. The study used a qualitative approach with a case study design. The data were gained by evaluating the students' writing through an automated writing evaluation program and the type of writing evaluated in the study was application letter. Then, the data were analyzed through three phases; data reduction, data display, and conclusion drawing. As the result, there were 268 grammatical errors found in the students' application letters. From their classifications, these errors were categorized into 17 types, with missing an article, misspelling, capitalization, incorrect number agreement, and incorrect preposition as the highest frequency of errors found.
\end{abstract}

Keywords: Application Letter, Grammatical Errors, Vocational Education

\section{INTRODUCTION}

As one of the international languages, English has become one of the requirements in the professional world. English becomes a medium in communicating, not only on a daily basis among individuals and groups (Anggara \& Haryudin, 2020) but also for developing partnerships between companies. Moreover, English has also become one of the most spoken languages around the world, especially in global business connections. Thus, the capability in English as a means of communication, in both written and spoken, needs to be mastered by the students for improving their qualification and boost their career.

Preparing the students to the professional level, English mastery has been put as a mandatory subject in vocational education institutions. In its implementation, in any vocational education institutions, English is taught as a specific purpose (henceforth ESP) which focuses on the need on the specific field (Ayuningtyas, 2020; Buşu, 2019; Salmani-nodoushan, 2020). Different from English for Academic Purpose which focuses on improving students' English mastery for academic matters, ESP tends to deal with specific terminologies applied and used in working, by practitioners, as its major concern (Bekteshi \& Xhaferi, 2020), such as English for Tourism, English for Medical, English for Engineer, etc.

Institut Pariwisata dan Bisnis Internasional (henceforth IPB Internasional) Denpasar, as one of the tourism vocational institutes, has already implemented English learning as an ESP, with the focus of the learning is on Business English for Hospitality. In Business English for Hospitality subject, the students learn about the special terminology on Business, especially in Hospitality 
field, including business telephone, business letter, business plan, business presentation, business meeting, and business negotiation. Moreover, they also learn the theory and praxis of English Interview in theHospitality field, including resume, application letter, and interview questions. To enrich the learning experience, the students also apply their lessons through speaking simulation and writing workshops. However, from the preliminary observation, it was found several grammatical errors occurring in students' writing, especially on their application letters.

An pplication letter is one of the required documents in applying for a job. This is the initial stage for the recruiter to value the students' qualifications, whether they will meet the criteria or not. The recruiter will evaluate the content of the application letter and grade the students' English mastery in written communication. Therefore, the students need to pay attention to their English mastery in writing the application letter.

To write a clear and organized application letter, good grammatical quality is needed to avoid any grammatical errors. Writing has been a complex task for students to make, and in a foreign language praxis, the students face more difficulties regarding its formalities and comprehensibilities (Divsar \& Heydari, 2017). For any foreign language learner, making grammatical errors becomes a common phenomenon. This happens as the result of the natural language learning process where the foreign language learner tries to apply the target language and results in several deviations on the target language (Rahimi \& Tafazoli, 2014; Sawalmeh, 2013). The target language deviation is caused by incomplete learning, in which the students do not fully comprehend the target language construction (Guo, 2021; Rahman, 2019). Even though it is a common phenomenon, ignoring the errors may lead the students to perceive the error fossilization. Error fossilization is a situation when the errors which often occur in the target language are eventually considered correct by the foreign language learners (Harmer, 2007). Therefore, grammatical errors need to be investigated to avoid the risk of error fossilization among the students (Khansir, 2012).

Profoundly, grammatical error investigations had been conducted. Some prior research has already revealed some types of errors that occur in students' writings, including in essays (Elmahdi, 2015; Pouladian et al., 2017), argumentative texts (Rahmatunisa, 2014), recount texts (Anggara \& Haryudin, 2020), narrative texts (Kusumawardhani, 2015), synopsis (Rahman, 2019), and paragraphs (Al-khasawneh, 2014). However, based on these empirical studies, different types of writing carried out different types of errors. Therefore, this study investigated the types of grammatical errors occurring on students' application letters to seek the types of grammatical errors occurring in application letters.

As the grammatical errors occurring on students' application letter may influence the recruiter perception in grading the students' English mastery, the investigation of grammatical errors in students' application letter is necessary. By analyzing the grammatical errors made by the students, the result of the study can give insight for lecturers to enhance students' writing quality and to reduce the students' chances of making errors (Guo, 2021).

\section{METHOD}

This research applied a qualitative approach with a case study design. The case study can limit the scope of the study to a specific situation. The study was conducted at IPB Internasional with a total number of 45 second-year students participating in the research. These students were selected through purposive sampling, by selecting the students who were enrolled in Business 
English for Hospitality subject. Each student submitted one application letter which was written in English. Then, these letters were evaluated through an automated writing evaluation program. The evaluation result was then analyzed through three phases, including data reduction, data display, and conclusion drawing. Then, the result of data analysis was interpreted to seek the types of error commonly produced by the students in writing application letters.

\section{RESULTS AND DISCUSSION}

\section{Results}

This study has unraveled the types of grammatical errors found in the students' application letters. From 45 application letters submitted, a total of 268 grammatical errors was found and based on their classifications, these errors were categorized into 17 types, including missing an article, misspelling, capitalization, number agreement, incorrect preposition, missing a preposition, unnecessary article, word choice, verb form, unnecessary preposition, incorrect pronoun, subject-verb agreement, incorrect article, missing conjunction, missing a relative pronoun, double determiner, and genitive case. To identify the most common grammatical errors made by the students, the calculation of the error production has been displayed in Table 1.

Table 1. Grammatical Errors Found in Students' Application Letters

\begin{tabular}{cc}
\hline Types of Errors & Frequency \\
\hline Missing an article & 58 \\
Misspelling & 46 \\
Capitalization & 45 \\
Number Agreement & 28 \\
Incorrect Preposition & 24 \\
Missing a Preposition & 17 \\
Unnecessary Article & 10 \\
Word Choice & 10 \\
Verb form & 6 \\
Unnecessary Preposition & 6 \\
Incorrect Pronoun & 5 \\
Subject-verb agreement & 4 \\
Incorrect Article & 4 \\
Missing conjunction & 2 \\
Missing a relative pronoun & 1 \\
Double Determiner & 1 \\
Genitive Case & 1 \\
\hline Total & 268 \\
\hline
\end{tabular}

As has been displayed in the table above, the result of the study indicated that the students face some types of problems in their application letter writing. From 17 types of grammatical errors found, there were 5 types of grammatical errors commonly produced by the students, including missing an article, misspelling, capitalization, incorrect number agreement, and incorrect preposition. To gain better insight, the study also revealed the possible deviation explanation occurring on these types of errors. 


\section{Missing an Article}

Missing an article becomes the highest number of errors made by the students on their application letters with a total of 58 errors found. Missing an article occurs when the writer did not put an article in front of a noun or a noun phrase. This kind of grammatical error may lead to the reader's confusion as an article is used to determine the referent of a noun or a noun phrase in the sentence. Besides, an article can also be used as a determiner in singularity. Without having any article, the reader may confuse in determining whether the noun or noun phrase is singular or plural form. An example of the missing article case found in the study can be shown as follow:

[Error] I have been daily worker in Sanak Retreat Bali as a Waitress. (Lt.1)

[Correction] I have been a daily worker in Sanak Retreat Bali as a Waitress.

On the example above, it is clear that the word "daily worker" is classified as a noun phrase. As a noun phrase, it needs an article to determine the information, whether it is a piece of new information or a piece of old information. Moreover, deriving from the context, the omission of the article on the sentence may lead to confusion in determining the singularity of the word "daily worker". This may influence the interpretation of the meaning of the word which refers to the student's experience, whether he/she has been a daily worker for one time or more than once. Thus, adding an article " $a$ " will help the student to explain the context of the information clearer.

\section{Misspelling}

The second common grammatical errors found in students' application letters is misspelling. Misspelling is an error occurring when the writer misspells any letter in a word. In this case, there are some conditions that lead the word categorized as misspelled. First, the writer puts an incorrect arrangement of the letters. Second, the writer omits a letter or letters in the word. Third, the writer adds a letter or letters into the word. As the result, the misspelling error can create confusion for the reader in reading and interpreting the meaning of the word. One example of the misspelling case found in the study can be shown as follow:

[Error] Thank you for yout attention. (Lt.7)

[Correction] Thank you for your attention.

As shown in the example above, the word "yout" is misspelled. From the context, it can be interpreted that the student would likely type the word "your" and followed by the noun "attention". The misspelling occurred as the letter $\mathrm{R}$ and $\mathrm{T}$ are next to each other on the computer keyboard.

\section{Capitalization}

The next common grammatical error occurring in students' application letters is capitalization. Capitalization error is classified as a spelling error. Different from misspelling, capitalization happens when the writer does not put a capital letter at the beginning of a specific word, including name, proper noun, cities, countries, nationalities, languages, companies, religions, political parties, days, and months. One example of the capitalization case found in the study can be shown as follow:

[Error] I have worked for 1 year at FuramaXclusive resort seminyak. (Lt.42)

[Correction] I have worked for 1 year at FuramaXclusive resort Seminyak. 
On the example shown above, the word "seminyak" is termed as a name of a region in Bali. From the context, it can be considered as a capitalization error case since the student did not put a capital letter case at the beginning of the word "seminyak". Therefore, the student needs to put the capital letter " $\mathrm{S}$ " in the word "seminyak" to avoid the error in typing.

\section{Incorrect Number Agreement}

The incorrect number agreement becomes the next common grammatical errors found in students' application letters. This case of agreement error is closely related to the agreement between the form of singularity and plurality of nouns with a determiner. This error case happens when the writer pairs up an incorrect form of a noun or a noun phrase along with a determiner: the writer puts a singular noun or noun phrase form after a plural determiner and vice versa. This mismatch between the form of the noun or noun phrase and its determiner can lead to the reader's misinterpretation of the information conveyed in the sentence. One example of the incorrect number agreement case found in the study can be shown as follow:

[Error] I am a good candidate for this duties. (Lt.13)

[Correction 1] I am a good candidate for these duties.

[Correction 2] I am a good candidate for this duty.

As shown in the example above, the noun phrase "this duties" has an incorrect number agreement. This happens since the student put a singular determiner "this" in front of the word "duties", which is classified as a plural form of the word "duty". In dealing with this error, there are two corrections that can be provided. First, the student can transform the singular determiner "this" into its plural form, "these". Second, the student can transform the plural form of "duties" into its singular form, "duty".

\section{Incorrect Preposition}

The fifth common grammatical errors found in students' application letters is the incorrect preposition. An incorrect preposition error occurs when the writer mismatches a preposition to a noun or verb that could lead to different meanings or interpretations. The existence of prepositions can indicate how a noun or verb is connected to the context in the sentence. Consequently, mismatching the preposition word to another noun or verb can affect the meaning conveyed in the sentence. One example of the incorrect preposition case found in the study can be shown as follow:

[Error] I have 6 month experience in Pastry chef at Maya Hotel. (Lt.27)

[Correction] I have 6 month experience as Pastry chef at Maya Hotel.

In the example above, the preposition "in" is less appropriate for the noun phrase "Pastry Chef". From the context, pastry chef refers to a name of occupation, not a department or a place, and thus, it is more appropriate if the students could change the preposition "in" to be "as".

\section{Discussion}

The aim of this study is to investigate the grammatical errors found in students' application letters. The grammatical errors occurring in the students' application may lead to misinterpretation of the content and context of the application letter. As what has been revealed in the study, the students have made 268 grammatical errors in their application letter. This number represents the problems that the students need to be aware of and the English lecturer's duty to help the students in improving their writing quality. Comprehensive feedback may help 
the students to gain further explanation on the errors that they have made and it can decrease the chance of making the same error (Kao \& Reynolds, 2016). In addition, from the result of the classification of the error, missing an article, misspelling, capitalization, incorrect number agreement, and incorrect preposition become the common grammatical errors produced by the students in writing their application letter.

The article problems may occur since the students' source language, Bahasa Indonesia, has different usage of an article from the target language, English. The mastery of article usage in both languages influences the capability of students in putting the articles on the sentences. In English, the articles are differentiated into two forms, definite and indefinite articles. These kinds of article systems do not occur in their source language, and this may lead the students to confusion in applying which article should be put before the noun or noun phrase (Alhaisoni et al., 2017).

Then, the problem in misspelling and capitalization commonly happens due to the lack of students' attention on the writing. The misspelling occurred as the result of students' carelessness on the word's spelling and less attention to the meaning of the words they type (Divsar \& Heydari, 2017). This heedless attention to spelling, both misspelling and capitalization, needs to precisely be aware of since paying to details is one of the major concerns in any job recruitment.

On the other hand, the incomplete language learning process can lead to the deviation in using number agreement and preposition. In many cases, the students arrange the words and construct them as a sentence, without paying attention to their meaning (Divsar \& Heydari, 2017). This commonly happens as the result of less understanding of the pattern of the target language system. As the students see the pattern of the target language is quite similar to the source language, they form a sentence by translating the source language pattern into the target language pattern (Pouladian et al., 2017). Consequently, the sentence created seems right for them, as they do not fully understand the appropriateness of the words and the meaning behind the sentence that they made seen from the linguistics aspect. Therefore, these students still some assistance and feedback from the lecturer as they are unable to revise their writing by themselves (Kao \& Reynolds, 2016).

\section{CONCLUSION}

The current study helps to raise the awareness of the students on the grammatical errors produced in the application letter. With a total of 268 grammatical errors found, it revealed the 17 types of grammatical errors produced by the students with missing an article, misspelling, capitalization, incorrect number agreement, and incorrect preposition as the common grammatical errors found. These grammatical errors are the result of the incomplete learning of the target language pattern and lack of attention had by the students in seeking the context and meaning of the words used on the sentence. Therefore, the English lecturer's assistance and feedback are required to raise students' awareness of their grammatical errors and to avoid any similar potential errors happened in future writing.

\section{ACKNOWLEDGMENTS}

This research was supported by Institut Pariwisata dan Bisnis Internasional, Denpasar 


\section{REFERENCES}

Al-khasawneh, F. M. (2014). Error analysis of written English paragraphs by Jordanian undergraduate students. International Journal of English Language, Literature and Humanities, 2(8), 85-100.

Alhaisoni, E., Ram Gaudel, D., \& M. Al-Zuoud, K. (2017). Article errors in the English writing of Saudi EFL preparatory year students. Advances in Language and Literary Studies, 8(1), 72-78. https://doi.org/10.7575/aiac.alls.v.8n.1p.72

Anggara, Y., \& Haryudin, A. (2020). An error analysis of writing recount text based on gender. PROJECT (Professional Journal of English Education), 3(5), 614-619. https://doi.org/10.22460/project.v3i5.p614-619

Ayuningtyas, P. (2020). An exploration of anxiety towards English for specific purposes (ESP). Tell : Teaching of English Language and Literature, 8(1), 7-18.

Bekteshi, E., \& Xhaferi, B. (2020). An analysis of English for specific purposes among university students. Educational Process: International Journal, 9(2), 90-102. https://doi.org/10.22521/edupij.2020.92.2

Buşu, A. (2019). An outlook on medernism in teaching English for specific purposes. The European Proceedings of Social \& Behavioural Sciences, 1-7.

Divsar, H., \& Heydari, R. (2017). A corpus-based study of EFL learners' errors in IELTS essay writing. International Journal of Applied Linguistics and English Literature, 6(3), 143149. https://doi.org/10.7575/aiac.ijalel.v.6n.3p.143

Elmahdi, O. E. H. (2015). Sudanese EFL learners' sources of errors in the production of articles. British Journal of English Linguistics, 3(4), 25-32.

Guo, R. (2021). Pedagogical implications on error analysis in the high school. Modern Management Forum, 5(1), 247-250. https://doi.org/10.18686/mmf.v5i1.3297

Harmer, J. (2007). How to Teach English. Pearson Education Limited.

Kao, C.-W., \& Reynolds, B. L. (2016). Analyses of EFL teacher feedback on word choice errors from an on-line writing platform. The Academic Conference of Foreign Language Teaching and Intercultural Studies, May, 35-51.

Khansir, A. A. (2012). Error analysis and second language acquisition. Theory and Practice in Language Studies, 2(5), 1027-1032. https://doi.org/10.4304/tpls.2.5.1027-1032

Kusumawardhani, P. (2015). Error analysis in writing an English narrative composition. Lingua Cultura, 9(2), 132-136. https://doi.org/10.21512/lc.v9i2.824

Pouladian, N., Bagheri, M. S., \& Sadighi, F. (2017). An analysis of errors in writing skill of adult Iranian EFL learners preparing for the IELTS. International Journal of English Linguistics, 7(3), 85-96. https://doi.org/10.5539/ijel.v7n3p85

Rahimi, A., \& Tafazoli, D. (2014). Error analysis in technology-mediated communication: focus on EFL writing in synchronous and asynchronous modes of communication. Procedia - Social and Behavioral Sciences, 136(2014), 66-69. https://doi.org/10.1016/j.sbspro.2014.05.289

Rahman, I. A. (2019). Morphological errors analysis on students' synopsis writing. English Language in Focus (ELIF), 1(2), 81-88. https://doi.org/10.24853/elif.1.2.81-88

Rahmatunisa, W. (2014). Problems faced by Indonesian EFL learners in writing argumentative essay. English Review: Journal of English Education, 3(1), 1-9. http://journal.uniku.ac.id/index.php/ERJEE

Salmani-nodoushan, M. A. (2020). English for specific purposes: Traditions, trends, directions. Studies in English Language and Education, 7(1), 247-268.

Sawalmeh, M. H. M. (2013). Error analysis of written English essays: The case of students of the preparatory year program in Saudi Arabia. English for Specific Purposes World, 14(40), 1-17. 
